\title{
The endocrine milieu and CD4 T-lymphocyte polarization during pregnancy
}

\author{
Barbara Polese*, Virginie Gridelet, Eleni Araklioti, Henri Martens, Sophie Perrier d'Hauterive and \\ Vincent Geenen
}

GIGA-I3, Center of Immunoendocrinology, University of Liège, Liège, Belgium

Edited by:

Gaetano Santulli, Columbia

University, USA

Reviewed by:

Jeremiah Stitham, Yale University, USA

Xuanzhi Zhan, Vanderbilt University, USA

Brian Yee Hong Lam, University of Cambridge, UK

*Correspondence:

Barbara Polese, GIGA-/3, Center of Immunoendocrinology, University of Liege, CHU-B34, Sart Tilman, Liège B-4000, Belgium

e-mail: bpolese@ulg.ac.be
Acceptance of the fetal semi-allograft by the mother's immune system has become the focus of intensive research. CD4+ $T$ cells are important actors in the establishment of pregnancy. Th1/Th2 paradigm has been expanded to include CD4+ regulatory $T$ (Treg) and T helper 17 (Th17) cells. Pregnancy hormones exert very significant modulatory properties on the maternal immune system. In this review, we describe mechanisms by which the endocrine milieu modulates CD4 T cell polarization during pregnancy. We first focused on Treg and Th17 cells and on their importance for pregnancy. Secondly, we review the effects of pregnancy hormones [progesterone (P4) and estradiol (E2)] on immune cells previously described, with a particular attention to human chorionic gonadotropin (hCG). The importance of Treg cells for pregnancy is evidenced. They are recruited before implantation and are essential for pregnancy maintenance. Decreased number or less efficient Treg cells are implicated in fertility disorders. As for Th17 cells, the few available studies suggest that they have a negative impact on fertility. Th17 frequency is increased in infertile patients. With the combination of its pro-effects on Th2 and Treg cells and anti-effects on Th1 and Th17 cells, P4 contributes to establishment of a favorable environment for pregnancy. E2 effects are more dependent on the context but it seems that E2 promotes Treg and Th2 cells while it inhibits Th1 cells. hCG positively influences activities of Treg and uterine natural killer cells. This embryo signal is an essential actor for the success of pregnancy, both as the endocrine factor regulating P4 secretion by the ovarian corpus luteum, but also as a paracrine agent during implantation as well as an angiogenic and immunologic mediator during the course of gestation. Luteinizing hormone (LH) immune properties begin to be studied but its positive impact on Treg cells suggests that LH could be a considerable immunomodulator in the mouse.

Keywords: progesterone, estradiol, human chorionic gonadotropin, luteinizing hormone, regulatory $\mathrm{T}$ cells, $\mathrm{T}$ helper 17 cells, pregnancy

\section{INTRODUCTION}

Pregnancy constitutes an immunological paradox since it implies that a fetus semi-antigenically distinct from the mother is not rejected by her immune system from embryo implantation to delivery. Peter Medawar was the first to consider the fetus as a semiallograft and to suggest a major role for the immune system in ensuring maintenance of pregnancy (1). Since then, the establishment of tolerance of mother's immune system to the embryonic and fetal semi-allograft has become the focus of intensive research.

Uterine Natural Killer (uNK) cells have been demonstrated to be main actors of pregnancy with their effects on angiogenesis, vascular remodeling, trophoblast invasion, and cytokine production $(2,3)$. CD4+ T cells are also important actors in the establishment of a «pregnancy favorable environment», and the Th1/Th2 paradigm has been prevailing for years. Briefly, feto-maternal acceptance was explained by Th2 profile predominance essential for pregnancy while pro-inflammatory Th1 cytokines were shown to be downregulated (4). This Th1/Th2 paradigm has been expanded to include CD4+ regulatory $\mathrm{T}$ (Treg) cells and interleukin-17 (IL17) expressing $\mathrm{T}$ [T helper 17 (Th17)] cells since it appeared that some studies were not fitting with the original theory $(5,6)$.

The endocrine system is also essential for the programing of a tolerogenic environment favorable to embryo implantation and fetal development, in particular the pregnancy hormones progesterone (P4), estradiol (E2), and human chorionic gonadotropin (hCG) hormone. Actually, both endocrine and immune systems are intimately linked and pregnancy hormones exert very significant modulatory properties on the maternal immune system.

Here, we review the mechanisms by which the endocrine milieu modulates CD4 T-lymphocyte polarization during pregnancy. First, we will focus on Treg and Th17 cells, on their importance for pregnancy, as well as their implication in infertility disorders. Second, we will review the effects of pregnancy hormones on immune cells previously described, with a particular attention to hCG. 


\section{CD4 T CELLS IMPORTANT FOR PREGNANCY \\ TH1 AND TH2 CELLS}

$\mathrm{CD} 4+\mathrm{T}$ cells are heterogenous members of the adaptative immune system. Different subsets have been identified based on their distinct cytokine and transcriptional profiles. Each subset has different effector functions. To be short, Th1 cells are polarized by IL-12 and are characterized by high production of interferongamma (IFN $\gamma)$. Th 2 cells are polarized mainly by IL- 4 and produce a cytokine profile including IL-4, IL-5, IL-6, and IL-13. Th2 are important for the clearing of extra-cellular pathogens and for helping B cells to produce antibodies. A balance between Th1 and Th2 is important for immune response, and Th1 and Th2 differentiation is mutually exclusive (7). In the context of pregnancy, Th1/Th2 balance was seen as essential for determining fetus survival in the maternal uterus. Th2 predominance was considered to be essential for fetal survival while a polarized Th1 profile could promote fetal rejection $(4,8-11)$. Th1/Th2 proportions during human pregnancy are simplified in Figure 1. However, the Th1/Th2 paradigm has been challenged by some recent studies that, for example, showed that Th2 cytokines KO mice (IL-4/IL-10 double KO mice) had no fertility disorders (12). For a complete review about the questioning of Th1/Th2 paradigm, please refer to the comprehensive review of Chaouat (5).

\section{TREG CELLS}

During the 1990s, Sakaguchi identified a T cell subpopulation naturally present in the immune system indispensable for tolerance and immune homeostasis. Those cells specialized in suppression/regulation of the immune response were called Treg cells (18) that were characterized first by increased CD25 expression at their surface (18). In 2003, Foxp3 was then discovered as the specific transcription factor that induces Treg cell differentiation (19). Treg cells are phenotypically and functionally heterogenous. Currently, various subsets of Treg cells in immune system have been identified (20). One common classification distinguishes thymic Treg (tTreg) generated in the thymus by a selection process from peripheral Treg or inducible Treg (iTreg) developing in the periphery from naïve $T$ cells after antigenic stimulation. It has been shown that

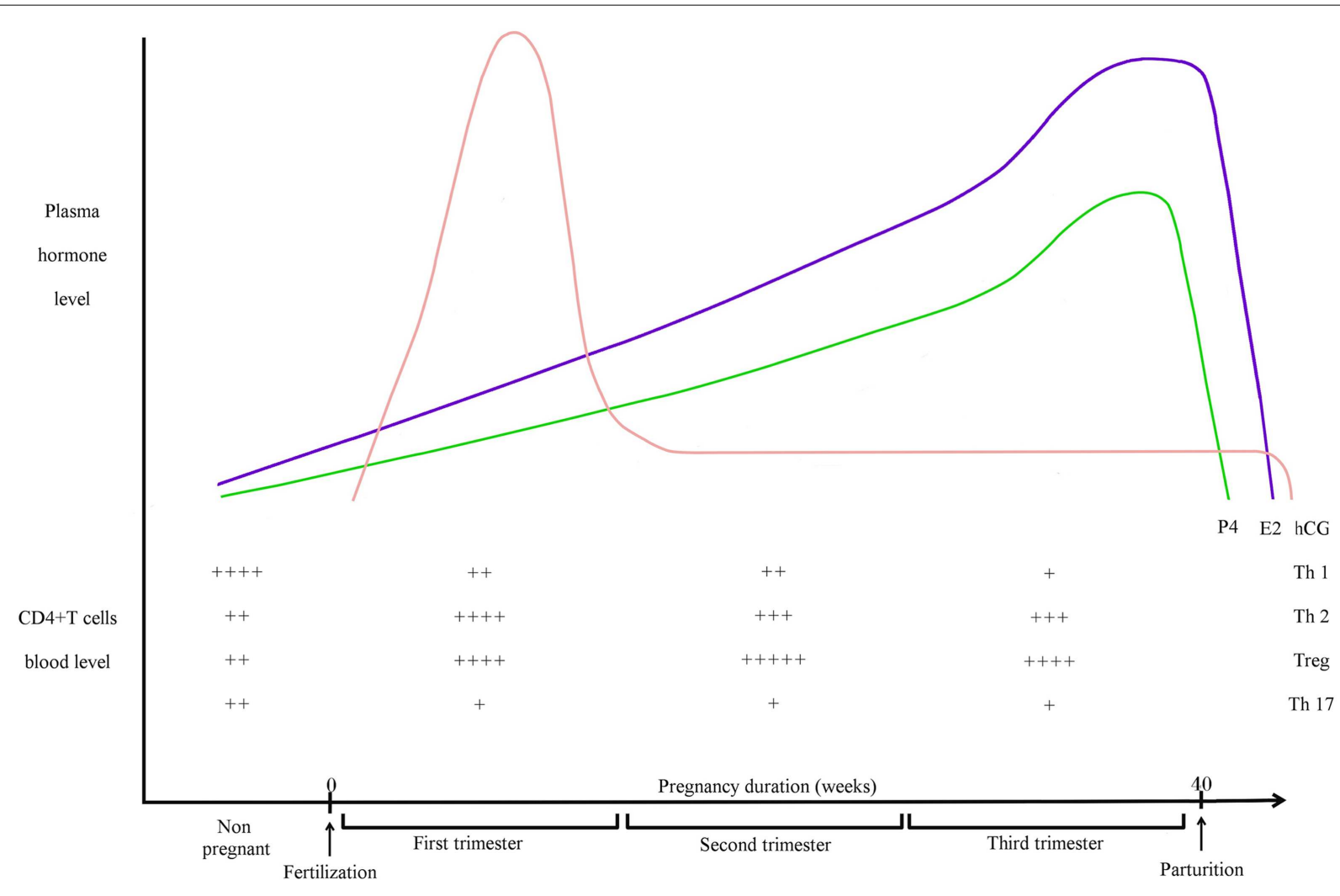

FIGURE 1 | Pregnancy hormones and CD4+T cells blood levels during human pregnancy. $\mathrm{hCG}$ is an embryonic signal that announces the presence of an embryo to the maternal organism. $h C G$ gene is transcribed as early as the eight-cells stage but it cannot be detected in the maternal blood before the second week after fertilization. Blood hCG concentration reaches a peak between the 8th and 11th week then it declines and stays low until the end of pregnancy. E2 is mainly produced by ovarian granulosa cells and by placenta. E2 concentration in maternal blood increases gradually after the first week, reaches a peak before parturition then drops few days after. Secreted mainly by corpus luteum then by placenta after 12 weeks of pregnancy, small quantities of P4 are already produced at the follicle stage. Then, P4 concentration in the blood increases strongly during the course of pregnancy to reach a peak before parturition. Relative blood levels of CD4+ T cells are compiled from different articles. During healthy pregnancy, Th1 cells are downregulated while Th2 cells are upregulated (13). Th2 predominance is considered to be essential for fetal survival. Pregnancy is also associated with a systemic expansion of Treg cells. The level of Treg cells is on the peak during the second trimester $(14,15)$. The circulating level of Th17 cell does not vary during human pregnancy and stays low (16). They are decreased during pregnancy when compared to non-pregnant women (17). 
CNS1 at the Foxp3 locus is not required for tTreg differentiation while it is essential for iTreg generation (21). The Treg cell family includes also IL-10-secreting CD4+ T regulatory- 1 cells $(\operatorname{Tr} 1)$ and TGF- $\beta$-secreting CD4 + Th cells (Th3). Treg cells exert their suppressive functions by different mechanisms such as secretion of inhibitory cytokines, cytolysis or metabolic disruption of the target cell and modulation of antigen presentation (20). As major actors for immunological tolerance, their impact on the acceptance of the fetus by the mother has been explored.

It is now more and more demonstrated that Treg cells are important cells for embryo implantation and pregnancy. Aluvihare et al. were the first to demonstrate that Treg cells mediate maternal tolerance to the fetus in the mouse (22). They observed a systemic expansion of the maternal CD4+CD25+ T cell pool during pregnancy and expression of Foxp3 by uterine CD4+CD25+ cells. They demonstrated also that CD25+ T cells depletion leads to gestation failure. Two studies confirmed this important role of Treg cells in human pregnancy $(14,23)$. Figure 1 depicts Treg cell blood levels during human pregnancy. Later, Zenclussen and her colleagues observed that a decrease in Treg cell activity leads to spontaneous abortion and they also demonstrated that adoptive transfer of Treg cells is able to prevent fetal rejection in a murine abortive model (24). They showed afterwards that the transferred Treg cells act by creating a privileged tolerant environment, and by up-regulating leukemia inhibitory factor (LIF), TGF- $\beta$, and HO-1 levels (25). Tilburgs et al. reported selective migration of specific Treg cells from blood to the decidua in human pregnancy (26). Then, seminal fluid was shown to drive expansion of CD4+CD25+ cells in mouse (27). By injecting antiCD25 mAb in pregnant mice at different time of pregnancy, Shima et al. demonstrated that Treg cells are necessary for implantation and maintenance of early pregnancy but not late pregnancy in allogeneic mice (28). Over the years, the in-depth study of Treg cells gave rise to the question of which subtype of Tregs is really acting during pregnancy (29). Samstein et al. studied this issue for the first time. They demonstrated that iTregs play important role in maintenance of pregnancy by using CNS1-deficient female. Those females present an increased frequency in fetal resorption (30). Zenclussen and her team were also interested in this subject. By using Helios as a marker of tTreg cells (31), they showed that tTreg cells are important for mouse pregnancy establishment while iTregs act at later pregnancy stages (32). Recently, Rowe et al. showed in mice that specific fetal Treg cells persist after delivery and re-accumulate during subsequent pregnancy in order to sustain protective regulatory memory to fetal antigen (33). The study of memory Treg cells across pregnancy remains another important topic to explore in the near future.

In addition, some papers evidenced a Treg cell dysregulation in infertile patients. A decrease in the decidual Treg cell number has been reported in human miscarriage (23). Endometrial expression of Foxp3 mRNA is decreased in women with primary unexplained infertility (34). Treg frequency in women with recurrent pregnancy lost do not fluctuate during menstrual cycle in comparison with fertile women, but Treg cell function in those women is deficient (35). The suppressor activity of iTregs in those patients is also decreased (36). Regarding preeclampsia (PE), it has been reported that PE patients present decreased Treg cell level in blood and in decidua $(17,37,38)$. Moreover, Treg cell function has been found to be decreased in PE patients (39). Recently, Inada et al. showed that the population of decidual non-proliferating Foxp3+ Tregs is significantly smaller in cases of miscarriages than in normal pregnancy (40). This suggests that non-proliferating Treg cells are important for induction of immune tolerance. Finally, in the CBA $\times$ DBA/2 well-known mouse model of abortion (41), a decreased number in Treg cells has also been reported (24). Altogether, those studies demonstrate that abnormalities in Treg cell frequency and function exert a negative impact upon fertility and confirm their importance for pregnancy.

\section{TH17 CELLS}

$\mathrm{T}$ helper 17 cells are a lineage of CD4+ T cells characterized by the secretion of IL-17a and IL-17f cytokines $(42,43)$ and by the expression of RORc (ROR $\gamma \mathrm{t}$ in mice) specific transcription factor (44). TGF- $\beta$, IL-6, IL-21, and IL-23 are important for their differentiation. It has to be mentioned that Th17 differentiation in mice is quite different from this process in humans (45). By the secretion of IL-17 cytokines, Th17 trigger recruitment, activation, and migration of neutrophils but also liberation of pro-inflammatory mediators. Th17 cells produce other cytokines too. IL-21 is involved in expansion of activated B cells and in class switching of immunoglobulin isotypes. The secretion of IL21 can also contribute to an autoamplification loop of Th17 cells by inducing their own differentiation. As for IL-22 production, it impacts on epithelial and endothelial barrier function through a dual effect on inflammation and tissue repair induction (46). Thus, Th17 cells are important effector cells for defense against extra-cellular pathogens. They are also associated with the pathogenesis of several autoimmune and inflammatory diseases (45). This complexity of Th17 cells is further amplified by their plasticity and instability. They can acquire other phenotypes depending on the cytokine environment (47). Giving the increasing demonstration of Th17 cell importance in the homeostasis of the immune system, their influence during pregnancy began to be investigated in the past few years.

Santner-Nanan et al. first found a lower Th17 cell frequency during pregnancy compared with non-pregnant women (17). Another article showed that the circulating level of Th17 cells does not vary during human pregnancy (see Figure 1) and that decidual levels of Th17 cells are higher than in peripheral blood (16). On the contrary, Mjosberg et al. found fewer Th17 cells in human decidua than in blood in early pregnancy and highlighted their nearly absence in decidua (48). Recently, it has been shown that NK cells promote tolerance by dampening Th17 cells via IFN $\gamma$ at materno-fetal interface, in humans and mice (49). All those results suggest that pregnancy is associated with a decrease in Th17 frequency. This is in agreement with another paper showing that placental trophoblasts in culture with T lymphocytes inhibit Th17 cells while promoting Th2 (50). Actually, not much is known about Th17 physiology during normal pregnancy, and most of articles focus on their presence in infertile patients.

The proportion of Th17 cells has been shown to be higher in blood and decidua of patients with unexplained recurrent spontaneous abortion $(51,52)$. Th17 factors like RORc and IL-17 are also higher in deciduas of those women. Nakashima et al. found also 
a high number of IL-17 positive cells in decidua of abortion case and suggested that Th17 cells could be involved in induction of inflammation in the late stage of abortion (53). Ito et al. suggested that Th17 cells could promote inflammation at the feto-maternal interface in preterm delivery, a disorder associated with infection and uterine inflammation (54). Furthermore, it was shown that circulating Th17 cells are increased in PE patients compared with healthy pregnant women (17). Others confirmed those results (39, 55). In a recent and well-thought article, it has been shown that NK cell-mediated inhibition of Th17 is lost in patients with recurrent spontaneous abortion, leading to a Th17 response and inflammation (49). Elevated IL-17 levels have also been observed in plasma of patients suffering from unexplained infertility (56). Altogether, those results indicate that Th17 cells seem to exert a negative impact upon fertility. Not much is known about their physiological role during estrous cycle and pregnancy but their presence is associated with inflammation and infertility. Given the importance of some temporary inflammation state for embryo implantation (57), it would be interesting to better study their exact importance during estrous cycle and early normal pregnancy.

\section{IMMUNOMODULATORY PROPERTIES OF PREGNANCY HORMONES \\ PROGESTERONE}

Progesterone is a crucial hormone in the female reproductive system. Secreted by the ovarian corpus luteum (CL) then by placenta after 12 weeks of pregnancy, it regulates endometrium modifications across the cycle and decidualization in order to prepare the uterus for embryo implantation. P4 plasma levels during human pregnancy are illustrated on Figure 1. Most importantly, P4 has a major impact on establishment and maintenance of pregnancy. Besides its endocrine effects, $\mathrm{P} 4$ has immunological properties. In particular, its immunosuppressive effects are known for a long time (58).

In 1995, Piccinni et al. demonstrated that P4 favors the development of Th2 CD4+ T cells (59). They suggested that P4 could be responsible at least in part for the Th2 predominance of pregnancy. A few years later, it was shown that P2 acts via an immunomodulatory protein called P4-inducible blocking factor (PIBF) that increased the production of Th2 cytokines by mice lymphocytes (60). This pro-Th2 effect of P4 is consistent with the increased IL-4 production observed during luteal phase of the ovarian cycle that is associated with elevated levels of P4 and estrogens (61). Moreover, P4 directly inhibits Th1 development while enhancing Th2 polarity in mouse cells (62), and P4 down-regulates the expression of IFN- $\gamma$ during luteal phase (63). The emergence of the Th1/Th2/Treg/Th17 paradigm led to the study of P4 on those cells too. Mjosberg et al. pointed out the $\mathrm{P} 4$ regulatory role on Treg cells during human pregnancy (64). In vivo and in vitro models indicate that $\mathrm{P} 4$ increases the proportion of Treg cells but also enhances their suppressive capacity (65). The association between Treg and P4 levels was confirmed in humans (66) and Lee et al. showed that $\mathrm{P} 4$ promotes the differentiation of human cord blood fetal T cells into Treg cells (67). P4 also promotes generation of iTreg cells that are highly stable (68), while it suppresses murine Th17 cells. In human and murine T cells, P4 inhibits differentiation of Th17 and decreases associated factors like RORc and
IL-17a. Recently, it was shown that P4 inhibits Th17 response while enhancing Treg development in murine vaginal gonococcal infection (69). Some researchers were curious to know how P4 acts on T cells. Membrane P4 receptors are found in human T cells (70). On the other hand, Treg cell expansion has been suggested to involve nuclear P4 receptors (65). Finally, Lee suggested that both nuclear and non-nuclear receptors are concerned (68). PIBF is one of the target genes of $\mathrm{P} 4$ in pregnancy lymphocytes. It signals via Jak1/Stat6 pathway to regulate cytokines expression (71, 72). Altogether, those studies suggest that P4 favors Th2 and Treg cells whilst dampening Th1 and Th17. Thus, P4 seems to participate in establishment of favorable environment for pregnancy by its effects on T cells.

\section{ESTROGENS}

Estrogens are also important for female reproductive tract, namely E2, estrone (E1), and estriol (E3). E2 is mainly produced by ovarian granulosa cells and by placenta. Figure 1 illustrates E2 plasma levels during human pregnancy. E2 immunomodulatory roles are multiple (73) but there is a paradox between their proand anti-inflammatory effects. Particularly, modifications in the clinical state of autoimmune diseases states observed in pregnant patients are distinct when looking at different kinds of diseases. For example, a remission of rheumatoid arthritis (RA) is usually observed in pregnant women (74) while a worsening of symptoms can be noticed during pregnancy for women suffering from systemic lupus erythematosus (SLE) (75). Those observations could be explained by the distinct effects of E2 on immune cell types.

Estradiol receptors (ER) $\alpha$ and $\beta$ are nuclear receptors expressed on most immune cells (76), including human and murine lymphocytes (77-80). Human CD4+ T cell express ER $\alpha$ at higher levels than B cells (81). These observations led to the study of the immunological properties of E2. E2 up-regulates IFN- $\gamma$ levels in murine splenic lymphocytes (82) and, in non-obese diabetic (NOD) mice, E2 increase IFN- $\gamma$ production by CD4+ Th1 cells (83). Maret has shown that E2 promotes Th1 cells responses and that requires $\mathrm{ER} \alpha(84)$. E2 modulates cytokines and chemokines expression by human and murine dendritic cells $(85,86)$, which influences secondarily T cell response. E2 acts also on CCR expression and function in murine T lymphocytes (87). In addition to pro-Th1 effects, E2 acts on Th2 cells. Indeed, the increase of IL-4 observed during the luteal phase (corresponding to P2 and E2 high levels) could be caused also by E2 (61). E2 also increases secretion of IL- 4 by CD4+ T cells as well as GATA-3 expression in mice (88). Anti- and pro-inflammatory effects have been reported for E2 since it enhances both IL-10 and IFN- $\gamma$ secretion in humans (89). So, E2 would have stimulating effects both on Th2 and Th1. With regard to the Th1/Th2 paradigm of pregnancy, both pro-Th1 and $\mathrm{Th} 2$ roles are paradoxical. Doria and others have explained this paradox by stating that, with high E2 levels such as in pregnancy, Th1 development is inhibited while Th2 polarity is favored. This is consistent with the improvement of Th1-mediated diseases and the worsening of Th2-mediated diseases observed during pregnancy (90). On the contrary, by promoting Th2 responses, E2 tends to worsen Th2-mediated diseases like SLE. Study of the E2 impact upon Treg cells has been widely explored, clarifying the situation. First, Polanczyk et al. discovered that E2 enhances Foxp3 
expression in vivo and in vitro (91). They suggested for the first time that $\mathrm{E} 2$ helps to regulate fetal tolerance during pregnancy by expanding Treg cells. One year later, the same team showed that E2 also increases the suppressive function of Treg cells. Similarities between pregnant mice and E2-treated mice suggested that E2 was mainly implicated in Treg cell expansion during pregnancy (92). Again, they demonstrated that $\mathrm{E} 2$ reduces activation of effector $\mathrm{T}$ cells while promoting Treg cell function in mice (93). Prieto et al. also showed that E2 promotes human Treg cell proliferation and enhances their suppressive functions (94). By showing that Treg cell frequency and E2 levels are correlated in humans, Arruvito et al. corroborated the pro-Treg effect of E2 (35). This correlation between E2 and Treg cells was confirmed in mouse models by Tai et al., who demonstrated that $\mathrm{E} 2$ addition converts $\mathrm{CD} 4+\mathrm{CD} 25-$ $\mathrm{T}$ cells in CD4+CD25+ Treg cells and enhances Foxp3 and IL10 expression (95). Later, Valor et al. confirmed that E2 enhances Treg cell number and function in humans (96). Concerning Th17 cells, it has been shown for a long time that $\mathrm{E} 2$ suppresses experimental allergic encephalomyelitis (EAE), a Th17-mediated disease $(97,98)$, and E2 inhibits IL-17 production by murine lymphocytes (99). On the contrary, Khan et al. found that E2 promotes IL-17 production as well as ROR $\gamma$ expression in stimulated splenocytes in mice (100). Even if those studies revealed contradictory results, they suggest that $\mathrm{E} 2$ regulates Th17 cells, perhaps depending on the context. In EAE, the E2 protective effects seem to be due to Th17 inhibition (101). Recently, it has been also shown that E2 exerts inhibitory effects on Th17 cells in the bone environment (102). Ovariectomized mice have increased Th17 cells and associated factors in bone marrow, and this was reversed by E2 supplementation. So, it seems that E2 impact on Th17 depends on the tissue and disease context. However, most studies tend to show that E2 has an inhibitory role on Th17 cells. Concerning the impact of $\mathrm{E} 2$ on $\mathrm{T}$ cells, we can conclude that they are quite large. $\mathrm{E} 2$ can promote Th1, Th2, Treg, and Th17 cells depending on the context. E2 have also inhibitory impact on those cells. During pregnancy, it seems that E2 favors Th2 and Treg cell development while it dampens Th1 responses. There has been no study so far to explore the effect of E2 on Th17 during pregnancy. Concerning the molecular mechanisms implicated in the immunomodulatory roles of E2, a recent article has shown that those E2 effects are mediated through its receptors and involve intracellular signaling pathways like ERK, CREB, and Akt, as well as antioxidant enzymes (103).

\section{HUMAN CHORIONIC GONADOTROPIN}

Human chorionic gonadotropin is the most specific embryoderived signal observed in humans and the $h C G$ gene is transcribed as early as the eight-cell stage, before embryo implantation (104-107). This signal announces the presence of an embryo to the maternal organism. The hCG plasma level during human pregnancy is depicted in Figure 1. hCG belongs to the glycoprotein hormone family such as luteinizing hormone ( $\mathrm{LH}$ ), folliclestimulating hormone (FSH), and thyroid stimulating hormone (TSH). Composed of two subunits, the alpha subunit is identical for all the members of the family while the hCG beta subunit shows $96 \%$ of homology with LH beta subunit. LH and hCG share the same LHCG receptor (LHCG-R). The basic endocrine function of hCG is to promote pregnancy via CL survival and stimulation of $\mathrm{P} 4$ production. Being released before embryo implantation, hCG also acts on endometrial cells in a paracrine way. For example, hCG induces morphological and functional differentiation of endometrial stromal cells into decidua (108). The investigators demonstrated that hCG induce prolactin secretion by human endometrial stromal cells, which is a sign of decidualization. Furthermore, hCG controls LIF and IL-6 secretion by human endometrial cells, and these two cytokines are known to influence blastocyst implantation (109). Indeed, we showed that endometrial epithelial cells cultured with hCG secrete higher LIF level while showing decreased IL-6 secretion. Furthermore, hCG has angiogenic and immunological properties, as reviewed in a recent paper (110). Briefly, hCG promotes angiogenesis by increasing vessel formation and pericyte sprouting and maturation in several in vitro and in vivo experimental models (111-115). hCG also influences angiogenic molecule production like vascular endothelial growth factor (VEGF) $(113,116)$. In this respect, hCG is considered to be an angiogenic factor (117). By promoting angiogenesis and vasculogenesis, hCG allows placenta to have adequate blood supply during the invasion of uterus and optimum nutrition to the fetus. The immunomodulatory properties of hCG are multiple and extremely important. First, hCG has a positive impact on uNK cells, the predominant leukocyte subtype of the gravid uterus that acts on establishment and maintenance of pregnancy, in humans and mice $(2,3,118)$. Particularly, uNK cells contribute to essential vascular changes by regulating the remodeling of decidual spiral arterioles $(119,120)$ and by secreting angiogenic factors as members of VEGF family (121). It has been shown that hCG regulates uNK proliferation (122). A dose-dependant increase in uNK proliferation is observed when isolated human uNK are incubated with hCG (123). Since uNK cells do not express the LHCG-R (124), hCG would act on mannose receptor (MR), which is expressed by human uNK (123). Furthermore, hCG promotes monocyte function and their IL-8 production (125), and also induces macrophage functions (126). This promotes clearance of apoptotic cells and defense against infections, two relevant mechanisms for pregnancy maintenance. hCG influences also dendritic cell differentiation and function, decreasing their ability to stimulate $\mathrm{T}$ cell proliferation (127). Finally, hCG has different effects on CD4+ T cells. During the 1970s, hCG was suggested to have effects on maternal lymphocytes (128). Khan revealed that hCG treatment of NOD mice prevent them to develop diabetes, a Th1 disease. The investigators demonstrated that hCG injections in NOD mice before the onset of diabetes avoid the apparition of inflammatory infiltrate in pancreas and reduce hyperglycemia. They proved that hCG inhibits murine Th1 cells and their production of IFN- $\gamma(129)$. A few years later, Khil confirmed those results and added new information. He showed that hCG effects on NOD mice implied an inhibition of $\mathrm{T}$ cell proliferative responses as well as an increase of $\mathrm{CD} 4+\mathrm{CD} 25+$ cells $(130)$. He revealed that $\mathrm{CD} 4+\mathrm{CD} 25+$ depletion cancels the protective effects of hCG treatment on diabetes development. Recently, studies about hCG impact on Treg cells have been carried out. Schumacher et al. explored Treg cell recruitment at the human materno-fetal interface and demonstrated with migration assays that hCG attracts them during early pregnancy (131). The same group also showed that hCG increases murine Treg cell frequency in vivo and their suppressive activity in vitro 


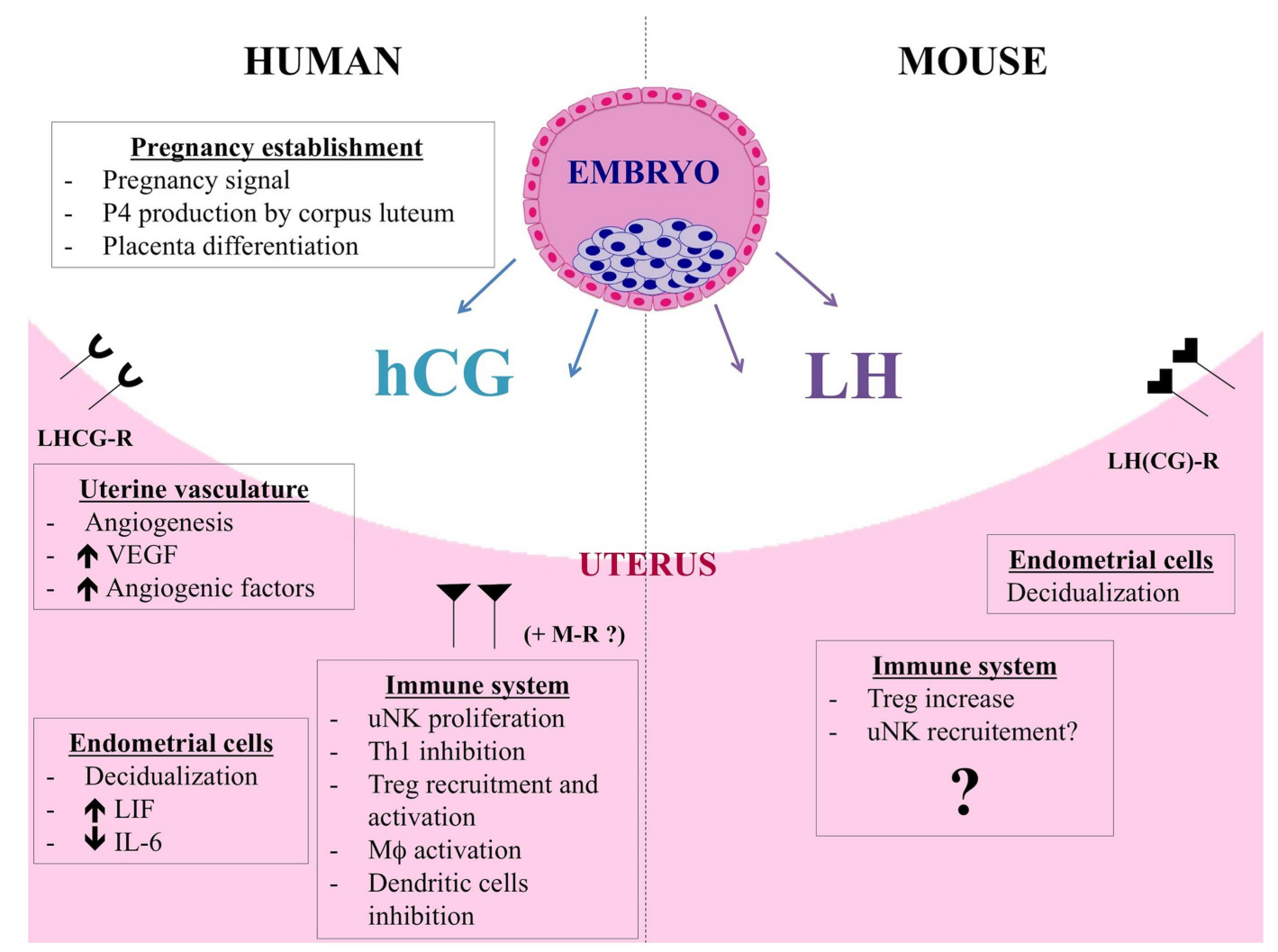

FIGURE 2 | hCG and LH functions during human and murine pregnancy Besides its endocrine role, hCG also acts on endometrial cells in a paracrine way and induces morphological and functional differentiation of endometrial stromal cells into decidua. hCG controls LIF and IL-6 secretion by human endometrial cells. By promoting angiogenesis, vasculogenesis, and angiogenic molecules production, hCG allows placenta to have adequate blood supply during the invasion of uterus and optimum nutrition to the fetus. The immunomodulatory properties of hCG are multiple. hCG has a positive impact on UNK cells, regulating their proliferation, putatively via mannose receptor (MR). Furthermore, hCG induces macrophage function, influences dendritic cell differentiation and function, and inhibits Th1 cells. Finally, hCG attracts Treg cells during early pregnancy and increases their frequency and suppressive activity. LH and hCG share the same LHCG receptor but LH is the only ligand of LHCG-R in mouse. hCG and LH are distinct molecules and actions of hCG cannot be claimed for LH. Murine blastocysts express the $L h$ gene and produce a bioactive LH signal thus showing that $\mathrm{LH}$ could be an important actor for the early dialog between the murine embryo and its mother. Data about the immunomodulatory roles of LH are scarce. LH could contribute to fetal tolerance by acting on murine Treg cells, similarly to hCG. LH would have also an impact on uNK cell recruitment.
(132). hCG treatment of abortion-prone female increases Treg cell numbers and reduces abortion rates. Thus, among its numerous functions during pregnancy affecting the fetus, placenta, and uterus (133), hCG has multiple immunomodulatory roles. In particular, the hCG effects on Treg and uNK cells, two major immune cell populations for pregnancy, demonstrate the importance of this embryo signal as an immune regulator during pregnancy. The different actions of hCG are summarized in Figure 2.

In humans, hCG shares its receptor with LH, a gonadotropin produced by the pituitary gland. Essential for reproduction, its fundamental functions are to initialize the final oocyte maturation and trigger ovulation during estrous cycle. LH controls P4 production by CL and if pregnancy occurs, hCG takes over the role of $\mathrm{LH}$ on $\mathrm{P} 4$ regulation. For pregnancy establishment, $\mathrm{LH}$ contributes to decidualization triggering. Mouse genome does not include a chorionic gonadotropin gene, and $\mathrm{LH}$ is therefore the only ligand of LHCG-R in mice. But hCG and LH are distinct molecules and actions of hCG cannot be claimed for LH (134). Data about the immunomodulatory roles of LH is scarce. Very recently, Schumacher has shown that LH could contribute to fetal tolerance by acting on murine Treg cells (135), following the example of hCG. Indeed, they showed that LH increases Treg cells peripherally and locally. They found also that $\mathrm{LH}$ injections reduce the abortion rates in abortion-prone mice. Earlier, we demonstrated that murine blastocyst express the $L h$ gene and produce a bioactive $\mathrm{LH}$ signal (136). Indeed, we detected $L h$ transcripts in blastocysts and the $\mathrm{LH}$ protein in their culture media. This $\mathrm{LH}$ is able to stimulate testosterone production by Leydig cells, and is thus bioactive. Furthermore, we detected $l$ hcgr transcripts in mouse endometrium and the higher expression level was observed during the theoretical embryo implantation period. Thus, we suggested that LH could be an important actor for the early dialog between the murine embryo and its mother (136). The results of Schumacher et al. confirm this hypothesis. Furthermore, Van den Heuvel et al. explored adhesion properties of human lymphocytes in uterus and revealed that adhesion was increased under LH surge (137). The authors 
suggested that LH could activate adhesion molecules on the surface of uNK precursors, thereby enhancing their recruitment in the uterus. In their review, the same team puts forward the hypothesis that cyclic hormonal variation could generate a favorable period for uNK cell recruitment via expression of adhesion molecules. They suggest again that LH would have an impact on uNK cell recruitment (138). Altogether, those studies show that $\mathrm{LH}$ also exerts immunomodulatory roles. LH can regulate Treg cells and would act on recruitment of uNK cells. The study of immunological properties of $\mathrm{LH}$ is at the beginning but the expression of $\mathrm{LH}$ receptor by $\mathrm{T}$ lymphocytes (124) suggests that other functions could be explored. LH actions during murine gestation are summarized in Figure 2.

\section{CONCLUSION}

Nowadays, uNK cells are considered as essential immune cells for pregnancy establishment and maintenance. CD4+ T cells are also important actors with Th2 being increased during pregnancy while Th1 have to be decreased for gestation to run smoothly. The importance of Treg cells for embryo implantation and pregnancy is also more and more evidenced. They are recruited before implantation to induce a favorable environment for embryo nidation. Afterwards, they are essential for maintenance of pregnancy. On the other hand, decreased number or less efficient Treg cells are implicated in fertility disorders. With regard to Th17 cells, the few available studies seem to indicate that they have a negative impact on fertility. Indeed, Th17 frequency is increased in infertile patients. Concerning immune properties of pregnancy hormones, it appears that they have positive impact on cells indispensable for implantation and gestation. With the combination of its proeffects on Th2 and Treg cells, and anti-effects on Th1 and Th17 cells, $\mathrm{P} 4$ contributes clearly to establishment of favorable environment for pregnancy. E2 effects are more dependent on the context but it seems that E2 promotes Treg and Th2 cells while inhibiting Th1 cells.

Human chorionic gonadotropin positively influences the activities of Treg and uNK cells. This embryo signal is an essential actor for the success of pregnancy, both as the well-known endocrine factor regulating $\mathrm{P} 4$ secretion by the ovarian $\mathrm{CL}$, but also as a paracrine agent during implantation as well as an angiogenic and immunologic mediator during the course of gestation. $\mathrm{LH}$ immune properties begin to be studied but its positive impact on Treg cells suggests that LH could be a considerable immunomodulator. The timing of pregnancy hormones and CD4+ T cells levels during human pregnancy is simplified on Figure 1. Of course, endocrine system is not the only factor responsible for immune cell recruitment and activation during pregnancy. It was showed that Treg cells found during pregnancy react to paternal antigen (22, 24). Zhao et al. demonstrated that fetal alloantigens are responsible for Treg cell recruitment, excluding hormonal influence (139). To finally conclude, both allogeneic and hormonal stimulation are responsible for a harmonious regulation of the immune system leading to a successful pregnancy.

\section{ACKNOWLEDGMENTS}

Barbara Polese is Bachelor in biomedical sciences and is a Ph.D. Fellow supported by the Fund of Research in Industry and
Agriculture (FRIA) of Belgium. Vincent Geenen is Research Director of F.S.R.-NFSR of Belgium. These studies are supported by the Fund Leon Fredericq for biomedical research at the Liege University Hospital.

\section{REFERENCES}

1. Medawar P. Some immunological and endocrinological problems raised by the evolution of viviparity in vertebrates. Symp Soc Exp Biol (1953) 44:320-38.

2. Lash GE, Robson SC, Bulmer JN. Review: functional role of uterine natural killer (uNK) cells in human early pregnancy decidua. Placenta (2010) 31(Suppl):S87-92. doi:10.1016/j.placenta.2009.12.022

3. Yagel S. The developmental role of natural killer cells at the fetal-maternal interface. Am J Obstet Gynecol (2009) 201(4):344-50. doi:10.1016/j.ajog.2009. 02.030

4. Wegmann TG, Lin H, Guilbert L, Mosmann TR. Bidirectional cytokine interactions in the maternal-fetal relationship: is successful pregnancy a TH2 phenomenon? Immunol Today (1993) 14(7):353-6. doi:10.1016/01675699(93)90235-D

5. Chaouat G. The Th1/Th2 paradigm: still important in pregnancy? Semin Immunopathol (2007) 29(2):95-113. doi:10.1007/s00281-007-0069-0

6. Saito S, Nakashima A, Shima T, Ito M. Th1/Th2/Th17 and regulatory Tcell paradigm in pregnancy. Am J Reprod Immunol (2010) 63(6):601-10. doi:10.1111/j.1600-0897.2010.00852.x

7. Mosmann TR, Coffman RL. TH1 and TH2 cells: different patterns of lymphokine secretion lead to different functional properties. Annu Rev Immunol (1989) 7:145-73. doi:10.1146/annurev.iy.07.040189.001045

8. Lin H, Mosmann TR, Guilbert L, Tuntipopipat S, Wegmann TG. Synthesis of T helper 2-type cytokines at the maternal-fetal interface. J Immunol (1993) 151(9):4562-73.

9. Raghupathy R. Th1-type immunity is incompatible with successful pregnancy. Immunol Today (1997) 18(10):478-82. doi:10.1016/S0167-5699(97)01127-4

10. Piccinni MP, Beloni L, Livi C, Maggi E, Scarselli G, Romagnani S. Defective production of both leukemia inhibitory factor and type 2 T-helper cytokines by decidual $\mathrm{T}$ cells in unexplained recurrent abortions. Nat Med (1998) 4(9):1020-4. doi:10.1038/2006

11. Clark DA, Arck PC, Chaouat G. Why did your mother reject you? Immunogenetic determinants of the response to environmental selective pressure expressed at the uterine level. Am J Reprod Immunol (1999) 41(1):5-22. doi:10.1111/j.1600-0897.1999.tb00071.x

12. Svensson L, Arvola M, Sallstrom MA, Holmdahl R, Mattsson R. The Th2 cytokines IL-4 and IL-10 are not crucial for the completion of allogeneic pregnancy in mice. J Reprod Immunol (2001) 51(1):3-7. doi:10.1016/S01650378(01)00065-1

13. Saito S, Sakai M, Sasaki Y, Tanebe K, Tsuda H, Michimata T. Quantitative analysis of peripheral blood Th0, Th1, Th2 and the Th1:Th2 cell ratio during normal human pregnancy and preeclampsia. Clin Exp Immunol (1999) 117(3):550-5. doi:10.1046/j.1365-2249.1999.00997.x

14. Somerset DA, Zheng Y, Kilby MD, Sansom DM, Drayson MT. Normal human pregnancy is associated with an elevation in the immune suppressive CD25+ CD4+ regulatory T-cell subset. Immunology (2004) 112(1):38-43. doi:10.1111/j.1365-2567.2004.01869.x

15. Xiong YH, Yuan Z, He L. Effects of estrogen on CD4(+) CD25(+) regulatory $\mathrm{T}$ cell in peripheral blood during pregnancy. Asian Pac J Trop Med (2013) 6(9):748-52. doi:10.1016/S1995-7645(13)60131-5

16. Nakashima A, Ito M, Yoneda S, Shiozaki A, Hidaka T, Saito S. Circulating and decidual Th17 cell levels in healthy pregnancy. Am J Reprod Immunol (2010) 63(2):104-9. doi:10.1111/j.1600-0897.2009.00771.x

17. Santner-Nanan B, Peek MJ, Khanam R, Richarts L, Zhu E, Fazekas de St Groth $\mathrm{B}$, et al. Systemic increase in the ratio between Foxp3+ and IL-17-producing CD4+ T cells in healthy pregnancy but not in preeclampsia. J Immunol (2009) 183(11):7023-30. doi:10.4049/jimmunol.0901154

18. Sakaguchi S, Sakaguchi N, Asano M, Itoh M, Toda M. Immunologic selftolerance maintained by activated $\mathrm{T}$ cells expressing IL-2 receptor alpha-chains (CD25). Breakdown of a single mechanism of self-tolerance causes various autoimmune diseases. J Immunol (1995) 155(3):1151-64.

19. Hori S, Nomura T, Sakaguchi S. Control of regulatory T cell development by the transcription factor Foxp3. Science (2003) 299(5609):1057-61. doi:10.1126/science. 1079490 
20. Sakaguchi S, Miyara M, Costantino CM, Hafler DA. FOXP3+ regulatory T cells in the human immune system. Nat Rev Immunol (2010) 10(7):490-500. doi:10.1038/nri2785

21. Zheng Y, Josefowicz S, Chaudhry A, Peng XP, Forbush K, Rudensky AY. Role of conserved non-coding DNA elements in the Foxp3 gene in regulatory T-cell fate. Nature (2010) 463(7282):808-12. doi:10.1038/nature08750

22. Aluvihare VR, Kallikourdis M, Betz AG. Regulatory T cells mediate maternal tolerance to the fetus. Nat Immunol (2004) 5(3):266-71. doi:10.1038/ni1037

23. Sasaki Y, Sakai M, Miyazaki S, Higuma S, Shiozaki A, Saito S. Decidual and peripheral blood CD4+CD25+ regulatory $\mathrm{T}$ cells in early pregnancy subjects and spontaneous abortion cases. Mol Hum Reprod (2004) 10(5):347-53. doi:10.1093/molehr/gah044

24. Zenclussen AC, Gerlof K, Zenclussen ML, Sollwedel A, Bertoja AZ, Ritter $\mathrm{T}$, et al. Abnormal T-cell reactivity against paternal antigens in spontaneous abortion: adoptive transfer of pregnancy-induced CD4+CD25+ T regulatory cells prevents fetal rejection in a murine abortion model. Am J Pathol (2005) 166(3):811-22. doi:10.1016/S0002-9440(10)62302-4

25. Zenclussen AC, Gerlof K, Zenclussen ML, Ritschel S, Zambon Bertoja A, Fest $\mathrm{S}$, et al. Regulatory $\mathrm{T}$ cells induce a privileged tolerant microenvironment at the fetal-maternal interface. Eur J Immunol (2006) 36(1):82-94. doi:10.1002/eji.200535428

26. Tilburgs T, Roelen DL, van der Mast BJ, de Groot-Swings GM, Kleijburg C, Scherjon SA, et al. Evidence for a selective migration of fetusspecific CD4+CD25bright regulatory $\mathrm{T}$ cells from the peripheral blood to the decidua in human pregnancy. J Immunol (2008) 180(8):5737-45. doi:10.4049/ jimmunol.180.8.5737

27. Robertson SA, Guerin LR, Bromfield JJ, Branson KM, Ahlstrom AC, Care AS. Seminal fluid drives expansion of the CD4+CD25+ T regulatory cell pool and induces tolerance to paternal alloantigens in mice. Biol Reprod (2009) 80(5):1036-45. doi:10.1095/biolreprod.108.074658

28. Shima T, Sasaki Y, Itoh M, Nakashima A, Ishii N, Sugamura K, et al. Regulatory $\mathrm{T}$ cells are necessary for implantation and maintenance of early pregnancy but not late pregnancy in allogeneic mice. J Reprod Immunol (2010) 85(2):121-9. doi:10.1016/j.jri.2010.02.006

29. Saito S, Shima T, Inada K, Nakashima A. Which types of regulatory T cells play important roles in implantation and pregnancy maintenance? Am J Reprod Immunol (2013) 69(4):340-5. doi:10.1111/aji.12101

30. Samstein RM, Josefowicz SZ, Arvey A, Treuting PM, Rudensky AY. Extrathymic generation of regulatory $\mathrm{T}$ cells in placental mammals mitigates maternal-fetal conflict. Cell (2012) 150(1):29-38. doi:10.1016/j.cell.2012.05.031

31. Thornton AM, Korty PE, Tran DQ, Wohlfert EA, Murray PE, Belkaid Y, et al. Expression of Helios, an Ikaros transcription factor family member, differentiates thymic-derived from peripherally induced Foxp3+ T regulatory cells. J Immunol (2010) 184(7):3433-41. doi:10.4049/jimmunol.0904028

32. Teles A, Thuere C, Wafula PO, El-Mousleh T, Zenclussen ML, Zenclussen AC. Origin of Foxp3(+) cells during pregnancy. Am J Clin Exp Immunol (2013) 2(3):222-33.

33. Rowe JH, Ertelt JM, Xin L, Way SS. Pregnancy imprints regulatory memory that sustains anergy to fetal antigen. Nature (2012) 490(7418):102-6. doi:10.1038/nature 11462

34. Jasper MJ, Tremellen KP, Robertson SA. Primary unexplained infertility is associated with reduced expression of the T-regulatory cell transcription factor Foxp3 in endometrial tissue. Mol Hum Reprod (2006) 12(5):301-8. doi:10.1093/molehr/gal032

35. Arruvito L, Sanz M, Banham AH, Fainboim L. Expansion of CD4+CD25+ and FOXP3+ regulatory $\mathrm{T}$ cells during the follicular phase of the menstrual cycle: implications for human reproduction. J Immunol (2007) 178(4):2572-8. doi:10.4049/jimmunol.178.4.2572

36. Arruvito L, Sotelo AI, Billordo A, Fainboim L. A physiological role for inducible FOXP3(+) Treg cells. Lessons from women with reproductive failure. Clin Immunol (2010) 136(3):432-41. doi:10.1016/j.clim.2010.05.002

37. Sasaki Y, Darmochwal-Kolarz D, Suzuki D, Sakai M, Ito M, Shima T, et al. Proportion of peripheral blood and decidual CD4(+) CD25(bright) regulatory T cells in pre-eclampsia. Clin Exp Immunol (2007) 149(1):139-45. doi:10.1111/j.1365-2249.2007.03397.x

38. Jianjun Z, Yali H, Zhiqun W, Mingming Z, Xia Z. Imbalance of T-cell transcription factors contributes to the Th1 type immunity predominant in preeclampsia. Am J Reprod Immunol (2010) 63(1):38-45. doi:10.1111/j.16000897.2009.00763.x
39. Darmochwal-Kolarz D, Kludka-Sternik M, Tabarkiewicz J, Kolarz B, Rolinski J, Leszczynska-Gorzelak B, et al. The predominance of Th17 lymphocytes and decreased number and function of Treg cells in preeclampsia. JReprod Immunol (2012) 93(2):75-81. doi:10.1016/j.jri.2012.01.006

40. Inada K, Shima T, Nakashima A, Aoki K, Ito M, Saito S. Characterization of regulatory $\mathrm{T}$ cells in decidua of miscarriage cases with abnormal or normal fetal chromosomal content. J Reprod Immunol (2013) 97(1):104-11. doi:10.1016/j.jri.2012.12.001

41. Chaouat G, Clark D, Wegmann T. Genetic aspects of the CBA x DBA/2 and B10 x B10. A model of murine abortion and its prevention by lymphocytes immunisation. In: Allen W, Clark D, Gill T, Mowbray J, Robertson W editors. Early Pregnancy Loss: Mechanisms and Treatment. London: RCOG Press (1988). p. 89-105.

42. Park H, Li Z, Yang XO, Chang SH, Nurieva R, Wang YH, et al. A distinct lineage of CD4 T cells regulates tissue inflammation by producing interleukin 17. Nat Immunol (2005) 6(11):1133-41. doi:10.1038/ni1261

43. Harrington LE, Hatton RD, Mangan PR, Turner H, Murphy TL, Murphy $\mathrm{KM}$, et al. Interleukin 17-producing CD4+ effector T cells develop via a lineage distinct from the $\mathrm{T}$ helper type 1 and 2 lineages. Nat Immunol (2005) 6(11):1123-32. doi:10.1038/ni1254

44. Ivanov II, McKenzie BS, Zhou L, Tadokoro CE, Lepelley A, Lafaille JJ, et al. The orphan nuclear receptor RORgammat directs the differentiation program of proinflammatory IL-17+ T helper cells. Cell (2006) 126(6):1121-33. doi:10.1016/j.cell.2006.07.035

45. Maddur MS, Miossec P, Kaveri SV, Bayry J. Th17 cells: biology, pathogenesis of autoimmune and inflammatory diseases, and therapeutic strategies. Am J Pathol (2012) 181(1):8-18. doi:10.1016/j.ajpath.2012.03.044

46. Korn T, Bettelli E, Oukka M, Kuchroo VK. IL-17 and Th17 Cells. Annu Rev Immunol (2009) 27:485-517. doi:10.1146/annurev.immunol.021908.132710

47. Zhou L, Chong MM, Littman DR. Plasticity of CD4+ T cell lineage differentiation. Immunity (2009) 30(5):646-55. doi:10.1016/j.immuni.2009.05.001

48. Mjosberg J, Berg G, Jenmalm MC, Ernerudh J. FOXP3+ regulatory T cells and T helper 1, T helper 2, and T helper 17 cells in human early pregnancy decidua. Biol Reprod (2010) 82(4):698-705. doi:10.1095/biolreprod.109.081208

49. Fu B, Li X, Sun R, Tong X, Ling B, Tian Z, et al. Natural killer cells promote immune tolerance by regulating inflammatory TH17 cells at the human maternal-fetal interface. Proc Natl Acad Sci U S A (2013) 110(3):E231-40. doi:10.1073/pnas. 1206322110

50. Liu F, Guo J, Tian T, Wang H, Dong F, Huang H, et al. Placental trophoblasts shifted Th1/Th2 balance toward Th2 and inhibited Th17 immunity at fetomaternal interface. APMIS (2011) 119(9):597-604. doi:10.1111/j.1600-0463. 2011.02774.x

51. Wang WJ, Hao CF, Yi L, Yin GJ, Bao SH, Qiu LH, et al. Increased prevalence of T helper 17 (Th17) cells in peripheral blood and decidua in unexplained recurrent spontaneous abortion patients. J Reprod Immunol (2010) 84(2):164-70. doi:10.1016/j.jri.2009.12.003

52. Liu YS, Wu L, Tong XH, Wu LM, He GP, Zhou GX, et al. Study on the relationship between Th17 cells and unexplained recurrent spontaneous abortion. Am J Reprod Immunol (2011) 65(5):503-11. doi:10.1111/j.1600-0897. 2010.00921.x

53. Nakashima A, Ito M, Shima T, Bac ND, Hidaka T, Saito S. Accumulation of IL17-positive cells in decidua of inevitable abortion cases. Am J Reprod Immunol (2010) 64(1):4-11. doi:10.1111/j.1600-0897.2010.00812.x

54. Ito M, Nakashima A, Hidaka T, Okabe M, Bac ND, Ina S, et al. A role for IL-17 in induction of an inflammation at the fetomaternal interface in preterm labour. J Reprod Immunol (2010) 84(1):75-85. doi:10.1016/j.jri.2009.09.005

55. Toldi G, Rigo J Jr, Stenczer B, Vasarhelyi B, Molvarec A. Increased prevalence of IL-17-producing peripheral blood lymphocytes in pre-eclampsia. Am J Reprod Immunol (2011) 66(3):223-9. doi:10.1111/j.1600-0897.2011.00987.x

56. Ozkan ZS, Deveci D, Kumbak B, Simsek M, Ilhan F, Sekercioglu S, et al. What is the impact of Th1/Th2 ratio, SOCS3, IL17, and IL35 levels in unexplained infertility? J Reprod Immunol (2013) 103:53-8. doi:10.1016/j.jri.2013.11.002

57. Mor G, Cardenas I, Abrahams V, Guller S. Inflammation and pregnancy: the role of the immune system at the implantation site. Ann N Y Acad Sci (2011) 1221:80-7. doi:10.1111/j.1749-6632.2010.05938.x

58. Siiteri PK, Febres F, Clemens LE, Chang RJ, Gondos B, Stites D. Progesterone and maintenance of pregnancy: is progesterone nature's immunosuppressant? Ann N Y Acad Sci (1977) 286:384-97. doi:10.1111/j.1749-6632.1977. tb29431.x 
59. Piccinni MP, Giudizi MG, Biagiotti R, Beloni L, Giannarini L, Sampognaro S, et al. Progesterone favors the development of human T helper cells producing Th2-type cytokines and promotes both IL-4 production and membrane CD30 expression in established Th1 cell clones. J Immunol (1995) 155(1): 128-33.

60. Szekeres-Bartho J, Wegmann TG. A progesterone-dependent immunomodulatory protein alters the Th1/Th2 balance. J Reprod Immunol (1996) 31(12):81-95. doi:10.1016/0165-0378(96)00964-3

61. Faas M, Bouman A, Moesa H, Heineman MJ, de Leij L, Schuiling G. The immune response during the luteal phase of the ovarian cycle: a Th2type response? Fertil Steril (2000) 74(5):1008-13. doi:10.1016/S0015-0282(00) 01553-3

62. Miyaura H, Iwata M. Direct and indirect inhibition of Th1 development by progesterone and glucocorticoids. J Immunol (2002) 168(3):1087-94. doi:10.4049/jimmunol.168.3.1087

63. Dosiou C, Lathi RB, Tulac S, Huang ST, Giudice LC. Interferon-related and other immune genes are downregulated in peripheral blood leukocytes in the luteal phase of the menstrual cycle. J Clin Endocrinol Metab (2004) 89(5):2501-4. doi:10.1210/jc.2003-031647

64. Mjosberg J, Svensson J, Johansson E, Hellstrom L, Casas R, Jenmalm MC, et al. Systemic reduction of functionally suppressive CD4dimCD25highFoxp3+ Tregs in human second trimester pregnancy is induced by progesterone and 17beta-estradiol. J Immunol (2009) 183(1):759-69. doi:10.4049/jimmunol. 0803654

65. Mao G, Wang J, Kang Y, Tai P, Wen J, Zou Q, et al. Progesterone increases systemic and local uterine proportions of CD4+CD25+ Treg cells during midterm pregnancy in mice. Endocrinology (2010) 151(11):5477-88. doi:10.1210/en. 2010-0426

66. Weinberg A, Enomoto L, Marcus R, Canniff J. Effect of menstrual cycle variation in female sex hormones on cellular immunity and regulation. J Reprod Immunol (2011) 89(1):70-7. doi:10.1016/j.jri.2010.11.009

67. Lee JH, Ulrich B, Cho J, Park J, Kim CH. Progesterone promotes differentiation of human cord blood fetal $\mathrm{T}$ cells into $\mathrm{T}$ regulatory cells but suppresses their differentiation into Th17 cells. J Immunol (2011) 187(4):1778-87. doi:10.4049/jimmunol.1003919

68. Lee JH, Lydon JP, Kim CH. Progesterone suppresses the mTOR pathway and promotes generation of induced regulatory T cells with increased stability. Eur J Immunol (2012) 42(10):2683-96. doi:10.1002/eji.201142317

69. Xu L, Dong B, Wang H, Zeng Z, Liu W, Chen N, et al. Progesterone suppresses Th17 cell responses, and enhances the development of regulatory T cells, through thymic stromal lymphopoietin-dependent mechanisms in experimental gonococcal genital tract infection. Microbes Infect (2013) 15(12):796-805. doi:10.1016/j.micinf.2013.06.012

70. Dosiou C, Hamilton AE, Pang Y, Overgaard MT, Tulac S, Dong J, et al. Expression of membrane progesterone receptors on human $\mathrm{T}$ lymphocytes and Jurkat cells and activation of G-proteins by progesterone. J Endocrinol (2008) 196(1):67-77. doi:10.1677/JOE-07-0317

71. Kozma N, Halasz M, Polgar B, Poehlmann TG, Markert UR, Palkovics T, et al. Progesterone-induced blocking factor activates STAT6 via binding to a novel IL4 receptor. J Immunol (2006) 176(2):819-26. doi:10.4049/jimmunol.176.2.819

72. Szekeres-Bartho J, Halasz M, Palkovics T. Progesterone in pregnancy; receptorligand interaction and signaling pathways. J Reprod Immunol (2009) 83(12):60-4. doi:10.1016/j.jri.2009.06.262

73. Nadkarni S, McArthur S. Oestrogen and immunomodulation: new mechanisms that impact on peripheral and central immunity. Curr Opin Pharmacol (2013) 13(4):576-81. doi:10.1016/j.coph.2013.05.007

74. Ostensen M, Villiger PM. The remission of rheumatoid arthritis during pregnancy. Semin Immunopathol (2007) 29(2):185-91. doi:10.1007/s00281-0070072-5

75. Shabanova SS, Ananieva LP, Alekberova ZS, Guzov II. Ovarian function and disease activity in patients with systemic lupus erythematosus. Clin Exp Rheumatol (2008) 26(3):436-41.

76. Cunningham M, Gilkeson G. Estrogen receptors in immunity and autoimmunity. Clin Rev Allergy Immunol (2011) 40(1):66-73. doi:10.1007/s12016-0108203-5

77. Danel L, Souweine G, Monier JC, Saez S. Specific estrogen binding sites in human lymphoid cells and thymic cells. J Steroid Biochem (1983) 18(5):559-63. doi:10.1016/0022-4731(83)90131-0
78. Cohen JH, Danel L, Cordier G, Saez S, Revillard JP. Sex steroid receptors in peripheral $\mathrm{T}$ cells: absence of androgen receptors and restriction of estrogen receptors to OKT8-positive cells. J Immunol (1983) 131(6):2767-71.

79. Stimson WH. Oestrogen and human T lymphocytes: presence of specific receptors in the T-suppressor/cytotoxic subset. Scand J Immunol (1988) 28(3):345-50. doi:10.1111/j.1365-3083.1988.tb01459.x

80. Couse JF, Lindzey J, Grandien K, Gustafsson JA, Korach KS. Tissue distribution and quantitative analysis of estrogen receptor-alpha (ERalpha) and estrogen receptor-beta (ERbeta) messenger ribonucleic acid in the wildtype and ERalpha-knockout mouse. Endocrinology (1997) 138(11):4613-21. doi:10.1210/en.138.11.4613

81. Phiel KL, Henderson RA, Adelman SJ, Elloso MM. Differential estrogen receptor gene expression in human peripheral blood mononuclear cell populations. Immunol Lett (2005) 97(1):107-13. doi:10.1016/j.imlet.2004.10.007

82. Karpuzoglu-Sahin E, Hissong BD, Ansar Ahmed S. Interferon-gamma levels are upregulated by 17-beta-estradiol and diethylstilbestrol. J Reprod Immunol (2001) 52(1-2):113-27. doi:10.1016/S0165-0378(01)00117-6

83. Bao M, Yang Y, Jun HS, Yoon JW. Molecular mechanisms for gender differences in susceptibility to T cell-mediated autoimmune diabetes in nonobese diabetic mice. J Immunol (2002) 168(10):5369-75. doi:10.4049/jimmunol.168.10.5369

84. Maret A, Coudert JD, Garidou L, Foucras G, Gourdy P, Krust A, et al. Estradiol enhances primary antigen-specific CD4 T cell responses and Th1 development in vivo. Essential role of estrogen receptor alpha expression in hematopoietic cells. Eur J Immunol (2003) 33(2):512-21. doi:10.1002/immu.200310027

85. Liu HY, Buenafe AC, Matejuk A, Ito A, Zamora A, Dwyer J, et al. Estrogen inhibition of EAE involves effects on dendritic cell function. J Neurosci Res (2002) 70(2):238-48. doi:10.1002/jnr.10409

86. Bengtsson AK, Ryan EJ, Giordano D, Magaletti DM, Clark EA. 17beta-estradiol (E2) modulates cytokine and chemokine expression in human monocytederived dendritic cells. Blood (2004) 104(5):1404-10. doi:10.1182/blood2003-10-3380

87. Mo R, Chen J, Grolleau-Julius A, Murphy HS, Richardson BC, Yung RL. Estrogen regulates CCR gene expression and function in T lymphocytes. J Immunol (2005) 174(10):6023-9. doi:10.4049/jimmunol.174.10.6023

88. Lambert KC, Curran EM, Judy BM, Milligan GN, Lubahn DB, Estes DM. Estrogen receptor alpha (ERalpha) deficiency in macrophages results in increased stimulation of CD4+ T cells while 17beta-estradiol acts through ERalpha to increase IL-4 and GATA-3 expression in CD4+ T cells independent of antigen presentation. J Immunol (2005) 175(9):5716-23. doi:10.4049/jimmunol.175. 9.5716

89. Gilmore W, Weiner LP, Correale J. Effect of estradiol on cytokine secretion by proteolipid protein-specific $\mathrm{T}$ cell clones isolated from multiple sclerosis patients and normal control subjects. J Immunol (1997) 158(1):446-51.

90. Doria A, Iaccarino L, Sarzi-Puttini P, Ghirardello A, Zampieri S, Arienti S, et al. Estrogens in pregnancy and systemic lupus erythematosus. Ann N Y Acad Sci (2006) 1069:247-56. doi:10.1196/annals.1351.022

91. Polanczyk MJ, Carson BD, Subramanian S, Afentoulis M, Vandenbark AA, Ziegler SF, et al. Cutting edge: estrogen drives expansion of the CD4+CD25+ regulatory T cell compartment. J Immunol (2004) 173(4):2227-30. doi:10. 4049/jimmunol.173.4.2227

92. Polanczyk MJ, Hopke C, Huan J, Vandenbark AA, Offner H. Enhanced FoxP3 expression and Treg cell function in pregnant and estrogen-treated mice. J Neuroimmunol (2005) 170(1-2):85-92. doi:10.1016/j.jneuroim.2005.08.023

93. Polanczyk MJ, Hopke C, Vandenbark AA, Offner H. Estrogen-mediated immunomodulation involves reduced activation of effector $\mathrm{T}$ cells, potentiation of Treg cells, and enhanced expression of the PD-1 costimulatory pathway. J Neurosci Res (2006) 84(2):370-8. doi:10.1002/jnr.20881

94. Prieto GA, Rosenstein Y. Oestradiol potentiates the suppressive function of human CD4 CD25 regulatory $\mathrm{T}$ cells by promoting their proliferation. Immunology (2006) 118(1):58-65. doi:10.1111/j.1365-2567.2006.02339.x

95. Tai P, Wang J, Jin H, Song X, Yan J, Kang Y, et al. Induction of regulatory T cells by physiological level estrogen. J Cell Physiol (2008) 214(2):456-64. doi:10.1002/jcp. 21221

96. Valor L, Teijeiro R, Aristimuno C, Faure F, Alonso B, de Andres C, et al. Estradiol-dependent perforin expression by human regulatory T-cells. Eur J Clin Invest (2011) 41(4):357-64. doi:10.1111/j.1365-2362.2010.02414.x

97. Jansson L, Olsson T, Holmdahl R. Estrogen induces a potent suppression of experimental autoimmune encephalomyelitis and collagen-induced 
arthritis in mice. J Neuroimmunol (1994) 53(2):203-7. doi:10.1016/01655728(94)90030-2

98. Bebo BF Jr, Fyfe-Johnson A, Adlard K, Beam AG, Vandenbark AA, Offner $\mathrm{H}$. Low-dose estrogen therapy ameliorates experimental autoimmune encephalomyelitis in two different inbred mouse strains. J Immunol (2001) 166(3):2080-9. doi:10.4049/jimmunol.166.3.2080

99. Wang C, Dehghani B, Li Y, Kaler LJ, Vandenbark AA, Offner H. Oestrogen modulates experimental autoimmune encephalomyelitis and interleukin17 production via programmed death 1. Immunology (2009) 126(3):329-35. doi:10.1111/j.1365-2567.2008.03051.x

100. Khan D, Dai R, Karpuzoglu E, Ahmed SA. Estrogen increases, whereas IL-27 and IFN-gamma decrease, splenocyte IL-17 production in WT mice. Eur J Immunol (2010) 40(9):2549-56. doi:10.1002/eji.201040303

101. Lelu K, Laffont S, Delpy L, Paulet PE, Perinat T, Tschanz SA, et al. Estrogen receptor alpha signaling in $\mathrm{T}$ lymphocytes is required for estradiol-mediated inhibition of Th1 and Th17 cell differentiation and protection against experimental autoimmune encephalomyelitis. J Immunol (2011) 187(5):2386-93. doi:10.4049/jimmunol.1101578

102. Tyagi AM, Srivastava K, Mansoori MN, Trivedi R, Chattopadhyay N, Singh D. Estrogen deficiency induces the differentiation of IL-17 secreting Th17 cells: a new candidate in the pathogenesis of osteoporosis. PLoS One (2012) 7(9):e44552. doi:10.1371/journal.pone.0044552

103. Priyanka HP, Krishnan HC, Singh RV, Hima L, Thyagarajan S. Estrogen modulates in vitro $\mathrm{T}$ cell responses in a concentration- and receptor-dependent manner: effects on intracellular molecular targets and antioxidant enzymes. Mol Immunol (2013) 56(4):328-39. doi:10.1016/j.molimm.2013.05.226

104. Fishel SB, Edwards RG, Evans CJ. Human chorionic gonadotropin secreted by preimplantation embryos cultured in vitro. Science (1984) 223(4638):816-8. doi:10.1126/science. 6546453

105. Bonduelle ML, Dodd R, Liebaers I, Van Steirteghem A, Williamson R, Akhurst R. Chorionic gonadotrophin-beta mRNA, a trophoblast marker, is expressed in human 8-cell embryos derived from tripronucleate zygotes. Hum Reprod (1988) 3(7):909-14.

106. Lopata A, Hay DL. The potential of early human embryos to form blastocysts, hatch from their zona and secrete HCG in culture. Hum Reprod (1989) 4(8 Suppl):87-94. doi:10.1093/humrep/4.suppl_1.87

107. Jurisicova A, Antenos M, Kapasi K, Meriano J, Casper RF. Variability in the expression of trophectodermal markers beta-human chorionic gonadotrophin, human leukocyte antigen- $G$ and pregnancy specific beta- 1 glycoprotein by the human blastocyst. Hum Reprod (1999) 14(7):1852-8. doi:10.1093/humrep/14. 7.1852

108. Han SW, Lei ZM, Rao CV. Treatment of human endometrial stromal cells with chorionic gonadotropin promotes their morphological and functional differentiation into decidua. Mol Cell Endocrinol (1999) 147(1-2):7-16. doi:10.1016/ S0303-7207(98)00240-8

109. Perrier d'Hauterive S, Charlet-Renard C, Berndt S, Dubois M, Munaut C, Goffin $\mathrm{F}$, et al. Human chorionic gonadotropin and growth factors at the embryonicendometrial interface control leukemia inhibitory factor (LIF) and interleukin 6 (IL-6) secretion by human endometrial epithelium. Hum Reprod (2004) 19(11):2633-43. doi:10.1093/humrep/deh450

110. Tsampalas M, Gridelet V, Berndt S, Foidart JM, Geenen V, Perrier d'Hauterive S. Human chorionic gonadotropin: a hormone with immunological and angiogenic properties. J Reprod Immunol (2010) 85(1):93-8. doi:10.1016/j.jri.2009. 11.008

111. Berndt S, Blacher S, Munaut C, Detilleux J, Perrier d'Hauterive S, Huhtaniemi I, et al. Hyperglycosylated human chorionic gonadotropin stimulates angiogenesis through TGF-beta receptor activation. FASEB J (2013) 27(4):1309-21. doi:10.1096/fj.12-213686

112. Berndt S, Blacher S, Perrier d'Hauterive S, Thiry M, Tsampalas M, Cruz A, et al. Chorionic gonadotropin stimulation of angiogenesis and pericyte recruitment. J Clin Endocrinol Metab (2009) 94(11):4567-74. doi:10.1210/jc.2009-0443

113. Berndt S, Perrier d'Hauterive S, Blacher S, Pequeux C, Lorquet S, Munaut C, et al. Angiogenic activity of human chorionic gonadotropin through LH receptor activation on endothelial and epithelial cells of the endometrium. FASEB $J$ (2006) 20(14):2630-2. doi:10.1096/fj.06-5885fje

114. Herr F, Baal N, Reisinger K, Lorenz A, McKinnon T, Preissner KT, et al. HCG in the regulation of placental angiogenesis. Results of an in vitro study. Placenta (2007) 28(Suppl A):S85-93. doi:10.1016/j.placenta.2007.02.002
115. Bourdiec A, Bedard D, Rao CV, Akoum A. Human chorionic gonadotropin regulates endothelial cell responsiveness to interleukin 1 and amplifies the cytokine-mediated effect on cell proliferation, migration and the release of angiogenic factors. Am J Reprod Immunol (2013) 70(2):127-38. doi:10.1111/ aji. 12080

116. Reisinger $\mathrm{K}$, Baal N, McKinnon $\mathrm{T}$, Munstedt $\mathrm{K}$, Zygmunt $\mathrm{M}$. The gonadotropins: tissue-specific angiogenic factors? Mol Cell Endocrinol (2007) 269(1-2):65-80. doi:10.1016/j.mce.2006.11.015

117. Zygmunt M, Herr F, Keller-Schoenwetter S, Kunzi-Rapp K, Munstedt K, Rao $\mathrm{CV}$, et al. Characterization of human chorionic gonadotropin as a novel angiogenic factor. J Clin Endocrinol Metab (2002) 87(11):5290-6. doi:10.1210/jc. 2002-020642

118. Moffett A, Colucci F. Uterine NK cells: active regulators at the maternal-fetal interface. J Clin Invest (2014) 124(5):1872-9. doi:10.1172/JCI68107

119. Ashkar AA, Croy BA. Functions of uterine natural killer cells are mediated by interferon gamma production during murine pregnancy. Semin Immunol (2001) 13(4):235-41. doi:10.1006/smim.2000.0319

120. Zhang J, Chen Z, Smith GN, Croy BA. Natural killer cell-triggered vascular transformation: maternal care before birth? Cell Mol Immunol (2011) 8(1):1-11. doi:10.1038/cmi.2010.38

121. Hanna J, Goldman-Wohl D, Hamani Y, Avraham I, Greenfield C, NatansonYaron S, et al. Decidual NK cells regulate key developmental processes at the human fetal-maternal interface. Nat Med (2006) 12(9):1065-74. doi:10.1038/ nm1452

122. Bansal AS, Bora SA, Saso S, Smith JR, Johnson MR, Thum MY. Mechanism of human chorionic gonadotrophin-mediated immunomodulation in pregnancy. Expert Rev Clin Immunol (2012) 8(8):747-53. doi:10.1586/eci.12.77

123. Kane N, Kelly R, Saunders PT, Critchley HO. Proliferation of uterine natural killer cells is induced by human chorionic gonadotropin and mediated via the mannose receptor. Endocrinology (2009) 150(6):2882-8. doi:10.1210/en.20081309

124. Lin J, Lojun S, Lei ZM, Wu WX, Peiner SC, Rao CV. Lymphocytes from pregnant women express human chorionic gonadotropin/luteinizing hormone receptor gene. Mol Cell Endocrinol (1995) 111(1):R13-7. doi:10.1016/0303-7207(95) 03565-O

125. Kosaka K, Fujiwara H, Tatsumi K, Yoshioka S, Sato Y, Egawa H, et al. Human chorionic gonadotropin (HCG) activates monocytes to produce interleukin-8 via a different pathway from luteinizing hormone/HCG receptor system. J Clin Endocrinol Metab (2002) 87(11):5199-208. doi:10.1210/jc.2002-020341

126. Wan H, Versnel MA, Cheung WY, Leenen PJ, Khan NA, Benner R, et al. Chorionic gonadotropin can enhance innate immunity by stimulating macrophage function. J Leukoc Biol (2007) 82(4):926-33. doi:10.1189/jlb.0207092

127. Wan H, Versnel MA, Leijten LM, van Helden-Meeuwsen CG, Fekkes D, Leenen PJ, et al. Chorionic gonadotropin induces dendritic cells to express a tolerogenic phenotype. J Leukoc Biol (2008) 83(4):894-901. doi:10.1189/jlb. 0407258

128. Adcock EW III, Teasdale T, August CS, Cox S, Meschia G, Ballaglia TC, et al. Human chorionic gonadotropin: its possible role in maternal lymphocyte suppression. Science (1973) 181(4102):845-7. doi:10.1126/science.181.4102.845

129. Khan NA, Khan A, Savelkoul HF, Benner R. Inhibition of diabetes in NOD mice by human pregnancy factor. Hum Immunol (2001) 62(12):1315-23. doi:10.1016/S0198-8859(01)00368-8

130. Khil LY, Jun HS, Kwon H, Yoo JK, Kim S, Notkins AL, et al. Human chorionic gonadotropin is an immune modulator and can prevent autoimmune diabetes in NOD mice. Diabetologia (2007) 50(10):2147-55. doi:10.1007/s00125-0070769-y

131. Schumacher A, Brachwitz N, Sohr S, Engeland K, Langwisch S, Dolaptchieva $\mathrm{M}$, et al. Human chorionic gonadotropin attracts regulatory $\mathrm{T}$ cells into the fetal-maternal interface during early human pregnancy. J Immunol (2009) 182(9):5488-97. doi:10.4049/jimmunol.0803177

132. Schumacher A, Heinze K, Witte J, Poloski E, Linzke N, Woidacki K, et al. Human chorionic gonadotropin as a central regulator of pregnancy immune tolerance. J Immunol (2013) 190(6):2650-8. doi:10.4049/jimmunol.1202698

133. Cole LA. Biological functions of hCG and hCG-related molecules. Reprod Biol Endocrinol (2010) 8:102. doi:10.1186/1477-7827-8-102

134. Choi J, Smitz J. Luteinizing hormone and human chorionic gonadotropin: distinguishing unique physiologic roles. Gynecol Endocrinol (2014) 30(3):174-81. doi:10.3109/09513590.2013.859670 
135. Schumacher A, Poloski E, Sporke D, Zenclussen AC. Luteinizing hormone contributes to fetal tolerance by regulating adaptive immune responses. Am J Reprod Immunol (2014) 71(5):434-40. doi:10.1111/aji.12215

136. Gridelet V, Tsampalas M, Berndt S, Hagelstein MT, Charlet-Renard C, Conrath $\mathrm{V}$, et al. Evidence for cross-talk between the LH receptor and LH during implantation in mice. Reprod Fertil Dev (2013) 25(3):511-22. doi:10.1071/RD11241

137. van den Heuvel MJ, Horrocks J, Bashar S, Taylor S, Burke S, Hatta K, et al. Menstrual cycle hormones induce changes in functional interactions between lymphocytes and decidual vascular endothelial cells. J Clin Endocrinol Metab (2005) 90(5):2835-42. doi:10.1210/jc.2004-1742

138. van den Heuvel MJ, Xie X, Tayade C, Peralta C, Fang Y, Leonard S, et al. A review of trafficking and activation of uterine natural killer cells. Am J Reprod Immunol (2005) 54(6):322-31. doi:10.1111/j.1600-0897.2005.00336.x

139. Zhao JX, Zeng YY, Liu Y. Fetal alloantigen is responsible for the expansion of the CD4(+)CD25(+) regulatory $\mathrm{T}$ cell pool during pregnancy. J Reprod Immunol (2007) 75(2):71-81. doi:10.1016/j.jri.2007.06.052
Conflict of Interest Statement: The authors declare that the research was conducted in the absence of any commercial or financial relationships that could be construed as a potential conflict of interest.

Received: 07 May 2014; accepted: 21 June 2014; published online: 07 July 2014.

Citation: Polese B, Gridelet V, Araklioti E, Martens H, Perrier d'Hauterive S and Geenen $V$ (2014) The endocrine milieu and CD4 T-lymphocyte polarization during pregnancy. Front. Endocrinol. 5:106. doi: 10.3389/fendo.2014.00106

This article was submitted to Cellular Endocrinology, a section of the journal Frontiers in Endocrinology.

Copyright (c) 2014 Polese, Gridelet, Araklioti, Martens, Perrier d'Hauterive and Geenen. This is an open-access article distributed under the terms of the Creative Commons Attribution License (CC BY). The use, distribution or reproduction in other forums is permitted, provided the original author(s) or licensor are credited and that the original publication in this journal is cited, in accordance with accepted academic practice. No use, distribution or reproduction is permitted which does not comply with these terms. 